\title{
Rola i funkcja mediacji w konfliktach międzypokoleniowych
}

Celem prowadzonych rozważań jest wskazanie doniosłej roli mediacji w podejmowaniu międzypokoleniowych konfliktów, które mają miejsce w obrębie konfliktów interpersonalnych. Mediacja jako alternatywny sposób rozwiązywania sporów staje się coraz bardziej popularną metodą regulującą relacje między skonfliktowanymi stronami. Znajduje ona już uznanie nie tylko w dziedzinie prawa, ale także jako idea oraz postawa charakteryzująca jednostki gotowe do podjęcia konstruktywnego dialogu, porozumienia czy kreowania alternatywnych rozwiązań. W tym kontekście popularyzacja szeroko rozumianej facylitacji jako podejścia normującego funkcjonowanie rodziny znajduje swoje uzasadnienie. Celem prowadzonych refleksji jest poszukiwanie rozwiązań mających na względzie usprawnienie funkcjonowania rodziny w warunkach gwałtownych przemian społeczno-gospodarczych. Współczesne wyzwania wymagają od niej adaptacji innowacyjnych podejść, do których należą między innymi mediacja oraz zawierający się w niej wachlarz umiejętności, a także kompetencji, które warunkują nie tylko efektywny, ale i twórczy rozwój wszystkich członków rodziny.

Pierwsza część pracy odnosi się do uwarunkowań historyczno-społecznych mediacji, uwzględniając przede wszystkim kontekst rozwoju mediacji rodzinnych oraz próby dia- 
gnozy jej usprawniającej funkcji we wzajemnych odniesieniach skonfliktowanych stron. Dlatego druga część artykułu koncentruje się na dominującej kategorii konfliktów rodzinnych, jaką jest wadliwa komunikacja, oraz jej źródłach występowania, zwracając przede wszystkim uwagę na jej realne oddziaływanie na kondycję psychiczną oraz fizyczną uczestników sporu.

\section{Mediacje w rozwiązywaniu konfliktów społecznych}

Istota mediacji wyraża się w jej koncentracji na jednostce oraz sytuacji, która jest przez nią odczuwana jako trudna oraz uniemożliwiająca realizację jej osobistych potrzeb i interesów. W związku z tym szuka ona pomocy w postaci mediacji i obecności mediatora, którego zadaniem jest wspomaganie negocjacji z drugą skonfliktowaną stroną i stworzenie przestrzeni komunikacji, umożliwiającej wypracowanie porozumienia satysfakcjonującego obie strony. Co więcej, należy także wskazać nie tylko co, ale przede wszystkim kto znajduje się w centrum dyskursu mediacyjnego, umożliwiając tym samym wyeksponowanie źródeł powstania instytucji mediacji ${ }^{1}$.

Historyczna oraz międzynarodowa perspektywa mediacji jednoznacznie wskazuje, iż powstała ona w celu zneutralizowania negatywnych zjawisk społecznych ${ }^{2}$. W starożytnym Egipcie w VI wieku p.n.e. porozumienie było osiągane przy pomocy arbitra lub mediatora nazywanego najczęściej „przyjacielem” bądź „zacnym obywatelem”.

Termin „instytucja mediacji” jest rozumiany jako uzupełniająca forma wymiaru sprawiedliwości, na którą składają się zasady warunkujące jego istotę oraz dyskurs mediacyjny.

2 Por. S. Kardasiewicz, Historyczna $i$ międzynarodowa perspektywa mediacji, [w:] Mediacje. Teoria i praktyka, red. E. Gmurzyńska, R. Morek, Warszawa 2009, s. 31-47. 
Przedmiot sporu stanowiły w głównej mierze kwestie dotyczące rodzinnych spraw majątkowych czy nieruchomości, czyli spraw, których szybkie rozwiązanie znajdowało się $\mathrm{w}$ interesie wszystkich stron zaangażowanych w konflikt. Z kolei źródeł stosowania mediacji we współczesnych Chinach sięgających 2500 lat należy poszukiwać w filozoficzno-etycznych koncepcjach Konfucjusza, w których rozwiązywanie konfliktów opierało na trzech fundamentalnych zasadach. Pierwsza z nich odnosiła się do więzi i uczuć wewnątrz klanu, które były ważniejsze od interesów jego pojedynczych członków. Druga reguła dotyczyła prymatu panujących w rodzinie zasad etycznych nad dobrami materialnymi. Trzecia zasada, niejako wiążąc się z poprzednimi, odnosiła się do procesu sądowego, którego ewentualne rozpoczęcie oznaczało zdradę przyjętej hierarchii wartości i kodeksu etycznego, a w konsekwencji stratę twarzy rodu.

Ponieważ konflikt stanowi stały element rzeczywistości człowieka, próby jego konstruktywnego podejmowania stale ewoluowały. Koncentrowano się na poszukiwaniu porozumienia na drodze dialogu i pojednania, odchodząc jednocześnie od metod antagonizujących występujące między jednostkami różnice. Dlatego pierwsze rozprawy dotyczące mediacji pochodzą już z okresu starożytności Platona i Arystotelesa, stając się przedmiotem teoretyczno-praktycznych rozważań na przestrzeni wieków m.in. w kulturze żydowskiej, buddyjskiej, hinduskiej czy chrześcijańskiej.

Za kolebkę współczesnej mediacji uważa się Stany Zjednoczone powstałej między innymi na fali strajków między pracownikami a pracodawcami oraz kryzysu instytucji sądownictwa, który stanowił rezultat ponoszenia przez strony wysokich kosztów sądowych oraz strat wynikających ze złożoności procedur formalnych i czasu trwania postępowań sądowych. Wskazano na konieczność wprowadzenia regulacji prawnych umożliwiających 
szybszy i efektywniejszy dostęp społeczeństwa do wymiaru sprawiedliwości.

W kontekście prowadzonych rozważań istotne jest przywołanie jednej z teorii sprawiedliwości (model sprawiedliwości naprawczej), w której funkcjonuje także instytucja mediacji. Stanowi ona odpowiedź na dominujący w XIX-wiecznej praktyce prawa karnego model retrybutywny, koncertujący się wokół sprawcy w celu przypisania i wykonania odpowiadającego jego czynowi karze. W centrum podobnego modelu znajdują się winowajca, wymierzona przez aparat państwowy kara oraz przywrócenie naruszonego porządku społecznego. $\mathrm{Z}$ kolei w modelu restytutywnym, właściwym dla alternatywnych sposobów rozwiązywania sporów, uwaga jest skupiona na stronie pokrzywdzonej oraz czynnościach o charakterze prewencyjno-resocjalizacyjnych wobec sprawcy. Istota sprawiedliwości naprawczej (restorative justice) koncentruje się wokół koncepcji „nadziei”, z kolei jej zwolenników określa się mianem „romantycznych rewolucjonistów”. Stanowi to rezultat założeń sprawiedliwości naprawczej, której celem jest rewolucja w przepisach postępowania karnego oraz podejścia do sposobu myślenia o karze oraz winowaj$\mathrm{cy}^{3}$. Co więcej, opisywany paradygmat wpisuje się w ideę udziału obywateli w wymiarze sprawiedliwości, co w kontekście demokratyzacji społeczeństw, tendencji wolnościowych czy szerzenia poczucia przejmowania odpowiedzialności jednostek za konflikty stanowi istotny element w budowie społecznej oraz prawnej płaszczyzny rozwoju alternatywnych sposobów rozwiązywania sporów. Instytucja mediacji towarzyszy sprawiedliwości naprawczej, a ich wartości upatruje się przede wszystkim w możliwości swobodnego i otwartego wypowiadania się osób pokrzywdzo-

3 Por. W. Zalewski, Wymiar sprawiedliwości, sprawiedliwość naprawcza, demokracja, [w:] Mediacja dla każdego, red. L. Mazowiecka, Warszawa 2010, s. 18. 
nych, ustaleniu i otrzymaniu stosownego odszkodowania czy sposobności dobrowolnego podjęcia przez sprawcę odpowiedzialności za wyrządzone krzywdy ${ }^{4}$.

U podstaw teorii sprawiedliwości naprawczej znajduje się przekonanie o możliwości przywrócenia ładu zarówno w kontekście ogólnospołecznym, jak i na linii ofiara - sprawca w drodze zawarcia wzajemnego porozumienia. Staje się to możliwe dzięki „oddaniu konfliktu” osobie pokrzywdzonej zarówno poprzez uznanie i realizację jej potrzeb oraz interesów, jak i umożliwienie sprawcy podjęcia zobowiązań i działań naprawczych, stanowiących formę zadośćuczynienia ofierze ${ }^{5}$. W ten sposób mediacja stanowi atrakcyjny i efektywny sposób podejmowania sporów, umożliwiając przywrócenie harmonii także w relacjach międzyludzkich. Teoria sprawiedliwości naprawczej stanowi istotny wskaźnik, w jaki sposób alternatywne sposoby rozwiązywania konfliktów kierują się w swych procedurach dobrem jednostki, które jest utożsamiane z wyrażanymi przez nią interesami, potrzebami czy oczekiwaniami.

Społeczny kontekst alternatywnych sposobów rozwiązywania sporów zawiera się w przywracaniu harmonii i ładu między skonfliktowanymi stronami na drodze decyzji co do wyboru formy i kształtowania się procesu dochodzenia do porozumienia. Rola trzeciej niezaangażowanej w spór strony polega na stworzeniu możliwości oraz warunków podjęcia konstruktywnego dialogu i zaoferowaniu jednocześnie swojej profesjonalnej pomocy w postaci wiedzy, umiejętności oraz kompetencji z zakresu zarządzania komunikacją oraz konfliktem. W Polsce pierwsze przypadki ugód z zakresu prawa prywatnego i przestępstw prywatnych były

Por. M. Płatek, Cele mediacji w ujęciu porównawczym, [w:] Mediacja dla każdego, dz. cyt., s. 26.

5 Por. J. Latała, Od idei odwetu po sprawiedliwość naprawcza. Rozważania nad resocjalizacyjnym charakterem instytucji mediacji po wyroku jako formy sprawiedliwości naprawczej, „Probacja” 2010 nr 2, s. 30 . 
podejmowane polubownie już XV wieku. Przykładem jest księstwo oleśnickie, w którym od XV do XVIII wieku funkcjonowała instytucja sędziego pokoju (wzorowanego na francuskiej procedurze cywilnej), którego funkcją było doprowadzenie zwaśnionych stron do porozumienia ${ }^{6}$.

Stworzenie w Polsce ram prawnych dla funkcjonowania mediacji jako instytucji alternatywnego sposobu rozwiązywania sporów wobec tradycyjnego postępowania sądowego rozpoczęło się wraz z nowelizacją kodeksu postępowania cywilnego z 28 lipca 2005 roku7 . Cechą nadrzędną mediacji jest rozwiązywanie, a nie rozstrzyganie konfliktu, jej fakultatywny, profilaktyczny oraz edukacyjny charakter. Niewątpliwie do istotniejszych cech mediacji należą także czas oraz niskie koszty postępowania. W porównaniu do tradycyjnego postępowania sądowego procedura mediacji nie rozstrzyga sporu na korzyść żadnej ze stron, nie jest prowadzone również postępowanie dowodowe. Natomiast formalne zakończenie sprawy nie wiąże się z wyrokiem niezawisłego sądu, a ze wspieranymi przez mediatora negocjacjami stron i wypracowanym przez nie obopólnie akceptowalnym porozumieniem ${ }^{8}$.

Nowelizacja kodeksu postępowania cywilnego wprowadziła instytucję mediacji nie tylko jako element unowocześniający polskie sądownictwo, ale także w celu podniesienia kultury i świadomości prawnej w społeczeństwie oraz edukacji w kierunku budowy społeczeństwa opartego na twórczym podejmowaniu konfliktów. Sprawy wyłą-

6 Por. S. L. Stadniczeńko, ADR $w$ stużbie osiagania harmonii spotecznej - eliminacji sporów $i$ konfliktów, [w:] Alternatywne formy rozwiązywania sporów $w$ teorii $i$ praktyce. Wybrane zagadnienia, red. H. Duszka-Jakimko, S. L. Stadniczeńko, Opole 2008, s. 197.

7 Ustawa z dnia 28 lipca 2005 r. o zmianie ustawy - Kodeks postępowania cywilnego, kodeks cywilny i ustawy o kosztach sądowych w sprawach cywilnych (Dz.U. z 2005 r. Nr 172, poz. 1438, z późn. zm).

8 Por. G. Nordhelle, Sztuka rozwiązywania konfliktów, Gdańsk 2010, s. 33n. 
czone z katalogu spraw stanowiących przedmiot mediacji, to m.in. kwestie z zakresu prawa rodzinnego (ustalenie ojcostwa, macierzyństwa), prawa osobowego (uznanie za zmarłego) czy prawa spadkowego (stwierdzenie nabycia spadku $)^{9}$. O atrakcyjności mediacji decyduje wiele czynników, a są nimi przede wszystkim odformalizowanie, wyrażające się $\mathrm{w}$ możliwości swobodnego wypowiadania się stron, wybór dogodnych terminów, godzin i czasów spotkań oraz brak elementu właściwego dla procedury sądowej, czyli postępowania dowodowego.

W procedurze mediacji strony mają sposobność kształtowania osobistej społeczno-prawnej rzeczywistości. Pojednane strony zdecydowanie rzadziej kontynuują spór $\mathrm{w}$ ramach tradycyjnego postępowania sądowego $\mathrm{w}$ porównaniu do osób, które podjęły się mediacji ${ }^{10}$. Dlatego nadrzędnego celu mediacji można upatrywać się nie tylko w finalnym spisaniu porozumienia, ale w odbudowie pozytywnych relacji między stronami, warunkujących w przyszłości pozytywną komunikację. Mediator nie powinien podejmować działań mających na celu bezwarunkowe podpisanie porozumienia, ponieważ istnieje wysokie prawdopodobieństwo, że skonfliktowane strony nawet w sytuacji wcześniejszego zakończenia procedury mediacji podejmą ponownie samodzielny wysiłek nawiązania dialogu i rozwiązania konfliktu, nie odwołując się przy tym do instancji sądu. Zadaniami i funkcjami mediatora są przede wszystkim pomoc $\mathrm{w}$ wypracowaniu porozumienia, zadawanie pytań, łagodzenie napięć, ocena realności formułowanych przez strony propozycji ugody.

Zasady postępowania mediacyjnego określone w kodeksie postępowania cywilnego wyraźnie wskazują, że procedura mediacji może być prowadzona zarówno w oparciu

$9 \quad$ Por. R. Cebula, Mediacja w polskim prawie cywilnym. Stan prawny na 1 grudnia 2012, Warszawa 2012, s. 4.

10 Por. tamże. 
o umowę o mediacji, jak i postanowienie sądu. Jego decyzja o skierowaniu sprawy do mediacji musi zapaść najpóźniej do końca zamknięcia pierwszego posiedzenia. Później jej ewentualne rozpoczęcie zależy wyłącznie od woli stron. Z punktu widzenia prowadzonych rozważań wydaje się istotne zwrócenie uwagi na wyjątki od powyższej zasady, do których zaliczają się sprawy o rozwód oraz separację, w których to sąd, biorąc pod uwagę dobro członków rodziny oraz ich potrzeby (np. sprawy o alimenty, ustalenie planu wychowawczego), dysponuje możliwością skierowania stron na mediację na każdym etapie postępowania sądowego.

Mediator organizuje postępowanie mediacyjne na podstawie indywidualnej oceny oraz przesłanek skłaniających go do wyznaczenia wspólnych bądź indywidualnych spotkań ze stronami. Do jego obowiązków należy także wyznaczenie czasu oraz miejsca odbycia się pierwszego spotkania mediacyjnego. $\mathrm{Z}$ przebiegu mediacji sporządza on stosowny protokół, w którym prócz uwzględnionych kwestii wymienionych powyżej zawiera także wynik mediacji. Protokół wraz z ugodą jest podpisywany przez mediatora oraz strony. Na dalszym etapie strony, podpisując ugodę, wyrażają jednocześnie zgodę na wystąpienie do sądu z wnioskiem o jej zatwierdzenie. Zajmie się on zbadaniem jej treści pod kątem zgodności z prawem lub zasadami współżycia społecznego, zamiaru obejścia prawa, występowania sprzeczności lub niezrozumiałych treści. Co ważne, zakres przedmiotowy ugody mediacyjnej jest nieograniczony, co oznacza, że strony stanowią źródło postanowień kształtujących formę porozumienia.

Zasady, które obowiązują mediatora w procedurze mediacji, stanowią zarówno fundament prawidłowego przeprowadzenia procedury mediacji, jak i stworzenia skonfliktowanym stronom przestrzeni dialogu i porozumienia ${ }^{11}$.

11 Przedstawione w niniejszym artykule reguły nie wyczerpują katalogu zasad kierowania się mediatora w postępowaniu mediacyjnym. Zob. 
Stanowią one także punkt odniesienia w sytuacjach, w których mediator nie jest pewny co do natury etycznej podejmowanych decyzji.

Zasada dobrowolności jest określana „podstawową wartością" mediacji, ponieważ wskazuje na samodzielność oraz autonomię skonfliktowanych stron, które wyrażają się zarówno w podjęciu przez strony decyzji o rozpoczęciu mediacji, jak i na dalszym etapie w finalnym kształcie porozumienia $^{12}$. Co więcej, strony, ponosząc koszty postępowania mediacyjnego i wyrażając zgodę nie tylko na spotkania, ale także na osobę mediatora, przyjmują odpowiedzialność za ich przebieg oraz próby rozwiązania konfliktu. Powyższa zasada sprzyja również zwiększeniu poczucia zaangażowania oraz wytrwałości w podejmowanych przez strony działaniach i zobowiązaniach. Jest to o tyle ważne, że skonfliktowane strony na każdym etapie mediacji mogą bez podawania przyczyny z niej zrezygnować. Dotyczy to również konfliktów, które zostały skierowane do mediacji na wniosek sądu. Praktyka mediacyjna wskazuje jednak jednoznacznie, że bez zasady dobrowolności istota oraz funkcja mediacji traci na znaczeniu i jej fundamentalnej roli w rozwiązywaniu konfliktu.

Zasada poufności znajduje praktyczne zastosowanie w budowaniu atmosfery wzajemnego zaufania, szczerości, dzielenia się problemami czy wątpliwościami, ponieważ w głównej mierze zobowiązuje ona mediatora do zachowania tajemnicy w związku z informacjami, które uzyskał w trakcie spotkań. Odnosi się ona nie tylko do całego postępowania mediacyjnego, ale także do jej rezultatów. W związku z tym strony mogą zastrzec, aby ich przypadek nie był uwzględniany np. w prowadzonych przez sądy

M. Jaksa, Mediacja cywilna z perspektywy doświadczeń mediatora. Analiza zasad mediacji w przepisach kodeksu postępowania cywilnego, [w:] Alternatywne formy..., dz. cyt., s. 76-98.

12 Por. tamże, s. $77 \mathrm{n}$. 
i ośrodki mediacyjne statystykach ${ }^{13}$. W określonych jednak przypadkach na wniosek stron mediator może być zwolniony z klauzuli poufności. Dodatkowo kodeks karny również wskazuje na sytuacje, w których mediator jest zobligowany do poinformowania organów ścigania o popełnieniu przestępstwa lub jego usiłowaniu ${ }^{14}$.

Zasada bezstronności decyduje o kształtowaniu atmosfery zaufania, otwartej i szczerej rozmowie mediatora ze stronami, które wierzą w jego postawę neutralności, odzwierciedlającej się w braku przychylności wobec którejkolwiek ze stron, propozycji rozwiązań czy argumentów. $\mathrm{Z}$ praktycznego punktu widzenia zachowanie całkowitej bezstronności mediatora wydaje się niemożliwe, aczkolwiek zarzut stron o stronniczości mediatora stanowi realne zagrożenie dla procedury mediacji, a więc także dojścia do porozumienia.

\section{Specyfika konfliktów międzypokoleniowych}

Przyjęty sposób ujęcia problemu koncentruje się na opisie natury konfliktów międzypokoleniowych, zwracając przy tym szczególną uwagę na kontekst komunikacji interpersonalnej, która obok społeczno-rozwojowych oraz osobowościowych uwarunkowań konfliktu decyduje nierzadko zarówno o powstaniu sporu, jak i jego pozytywnym zakończeniu.

Pokolenie należy zdefiniować jako

określoną liczbę roczników urodzenia danego społeczeństwa, stanowiącą ze względu na okres ich socjalizacji w dzieciństwie i młodości dające się wyodrębnić ogniwo genealogii kulturowej

\footnotetext{
13 Por. tamże, s. 80.

14 Ustawa z dnia 6 czerwca 1997 r. - Kodeks karny, art. 240. Niezawiadomienie o przestępstwie (Dz.U. 1997.88.553).
} 
i historycznej danej zbiorowości. Pokolenie jest związane z określonymi datami procesu dziejowego i stanowi określoną zbiorowość o pewnych wspólnych systemach wartości aspiracji ${ }^{15}$.

W kontekście rodziny konflikty międzypokoleniowe będą się odnosić kolejno do rodziców, dzieci, dziadków czy pradziadków. Z kolei kontekst konfliktu interpersonalnego, którego źródło w poniższych rozważaniach stanowi komunikacja, wskazuje na konieczność odniesienia się także do natury komunikacji rodzinnej oraz jej psychologicznych aspektów, determinujących podejmowane przez członków rodziny strategie rozwiązywania konfliktów.

Z uwagi na fakt, że proces porozumienia się, któremu jednostka poświęca swoją aktywność w ciągu dnia, zajmuje 85\% czasu, konflikty na tle komunikacji interpersonalnej decydują o istotnej roli jej pozytywnego funkcjonowania i rozwoju ${ }^{16}$. Podstawowy model porozumiewania się uwzględnia nadawcę i jego intencje przekazania określonych informacji, treść wiadomości oraz adresata, który interpretuje odebrane informacje, tj. nadaje im określone znaczenia. Klasyczna definicja komunikowania się, mówi, że komunikacja „to podejmowana $\mathrm{w}$ określonym kontekście wymiana werbalnych, wokalnych i niewerbalnych sygnałów (symboli) w celu osiągnięcia lepszego poziomu współdziałania"17. Przyjęta definicja zważa na wzajemność, czyli dwukierunkowość interakcji w celu wypracowania porozumienia co do rozumienia oraz interpretowania wspólnej rzeczywistości funkcjonowania. W kontekście mediacji oraz konstruktywnego podejmowania konfliktów powyżej wymienione elementy decydują o sukcesie bądź porażce prowadzonych między

15 B. Gołębiowski, Dialog pokoleń: studia nad socjologicznymi $i$ kulturowymi zagadnieniami dialogu $i$ następstwa pokoleń w Polsce XX wieku, Warszawa 1980, s. 8.

16 Por. K. Balawajder, Komunikacja, konflikty, negocjacje w organizacji, Katowice 1998, s. 12.

17 Z. Nęcki, Komunikacja międzyludzka, Kraków 1996, s. 109. 
stronami negocjacji. Praca mediatora ze stronami decyduje także o rozwoju ich kompetencji komunikacyjnych, które wyrażają się w stosowaniu właściwych werbalnych i niewerbalnych komunikatów. O poziomie tychże kompetencji decyduje nie tylko wiedza jednostki z zakresu procesów interpersonalnych, ale także jej wewnętrzna motywacja do podejmowania konstruktywnych zachowań ${ }^{18}$. Co więcej, proces porozumiewania jest przede wszystkim procesem społecznym, ponieważ odbywa się przy udziale co najmniej dwóch osób w określonym kontekście socjokulturowym; dynamicznym - ze względu na dominujące w nim elementy nadawania, odbierania, interpretowania, analizowania czy porządkowania informacji oraz nieuchronnym - z uwagi na fakt nieustannego funkcjonowania jednostki w przestrzeni publicznej, w której staje się on mimowolnie odbiorcą bądź nadawcą określonych treści ${ }^{19}$.

W przyjętych rozważaniach specyfika relacji międzypokoleniowych wynika w głównej mierze z systemowego ujęcia rodziny, które wskazuje, że rodzina jest pewną całością, czyli systemem wzajemnych powiązań i relacji, a jej kondycja, tj. funkcjonowanie, zależy od jakości relacji między poszczególnymi członkami rodziny ${ }^{20}$. Komunikację w rodzinie wyróżnia przede wszystkim duża częstotliwość oraz trwałość, które stanowią rezultat wspólnego dzielenia przestrzeni życiowej oraz silnych więzi emocjonalnych. W związku z tym strategie porozumiewania się dla poszczególnych rodzin uznaje się za wzorcowe oraz indywidualne $e^{21}$.

18 Por. S. P. Morreale, B. H. Spitzberg, J. K. Barge, Komunikacja między ludźmi. Motywacja, wiedza i umiejętności, red. nauk. U. Jakubowska, tłum. P. Izdebski, A. Jaworska, D. Kobylińska, Warszawa 2008, s. 87. Por. K. Bargiel-Matusiewicz, Negocjacje i mediacje, Warszawa 2010, s. 10.

20 Por. B. Harwas-Napierała, Komunikacja w rodzinie ujmowanej jako system relacji rodzice-dzieci, „Roczniki Socjologii Rodziny” 2006 t. 17, s. 222.

21 Por. tamże. 
Rodzina stanowi główną płaszczyznę przejawiania się międzypokoleniowych napięć, które nie są zawsze utożsamiane z przywoływanymi w poniższej pracy konfliktami. Rozumienie "napięć międzypokoleniowych” uwzględnia szeroki zakres przyjmowanych przez jednostek postaw, które zawierają się zarówno w kwestionowaniu przez ludzi młodych świata dorosłych, jak i w pokojowym kompromisie wyrażającym się w afirmacji aksjonormatywnego porządku dorosłych członków rodziny. Właściwa dla rodziny i jej członków specyfika funkcjonowania sprzyja występowaniu szczególnie silnych napięć. Jej heterogeniczność pod względem wieku członków rodziny decyduje o wzajemnych interferowaniu odmiennych systemów wartości, wzorców zachowań, strategii porozumiewania się czy także podejmowania konfliktów ${ }^{22}$.

Konflikt stanowi specyficzny rodzaj relacji, która wyłania się w chwili pojawienia się określonych kryteriów decydujących o powstaniu sytuacji konfliktowej, a którymi są: interakcja, poprzez którą unaoczniają się funkcjonujące między jednostkami różnice i dzięki której nabywają one świadomości o różnicach w wyrażanych potrzebach, interesach, wartościach czy dążeniach. Drugim istotnym elementem rozumienia konfliktu jest współzależność, która wyraża się w zakłócaniu realizacji potrzeb, interesów czy dążeń jednej ze stron. Dlatego sytuacji różnicy zdań nie należy bezpośrednio utożsamiać z powstaniem między jednostkami konfliktu, ponieważ decyduje to o szkodliwym ich antagonizowaniu oraz stwarzaniu wrażenia konieczności przyjęcia racji którejś ze stron. Trzeci element to niekompatybilność, która wyraża się w sprzeczności

22 Przywołana problematyka napięć międzypokoleniowych stanowi przyczynek do odrębnych refleksji, które wykraczają poza zakres przedmiotowy niniejszej pracy. Zob. W. Wrzesień, Relacje międzypokoleniowe a rodzina, "Roczniki Socjologii Rodziny” 2000 t. 12, s. $65-67$. 
interesów i dążeń jednostek ${ }^{23}$. W związku z tym konflikt może być rozumiany, jako „[...] forma współzawodnictwa między ludźmi lub grupami ludzi. Jest to sytuacja, w której co najmniej dwie zależne od siebie osoby spierają się o ograniczone zasoby bądź o realizację interesów, które są - lub wydają się - niemożliwe do pogodzenia"24. Zwraca się uwagę przede wszystkim na osobisty oraz indywidualny wymiar postrzegania konfliktu przez jednostkę, która ze względu na przekonanie o niemożności realizacji określonych celów bez drugiej strony odczuwa ją jako sytuację trudną ${ }^{25}$.

Sytuacja konfliktowa, stanowiąc nierozłączny element relacji międzyludzkich, a więc także i interakcji rodzinnych, jest katalizatorem pozytywnych zachowań bądź czynnikiem hamującym we wspólnym funkcjonowaniu członków rodziny. Koncentracja autorki na generowaniu konfliktów rodzinnych uwarunkowanych wadliwą komunikacją decyduje o wskazaniu wybranych kardynalnych błędów popełnianych przez członków rodziny w procesie porozumiewania się ${ }^{26}$. Do „reguł katastrofalnego porozumiewania się" zalicza się między innymi kwestionowanie wszystkiego, co jedna strona mówi o drugiej, czy przywo-

23 Por. S. P. Morreale, B. H. Spitzberg, J. K. Barge, Komunikacja między ludźmi, dz. cyt., s. 473.

A. Cybulka, Konflikt, [w:] Mediacja. Teoria i praktyka, dz. cyt., s. 52. „Sytuacja trudna” jest rozumiana jako zespół czynników, stanowiących „zagrożenie dla jednostki - sygnalizowane lub bezpośrednio doznawane - lub zakłócają bądź uniemożliwiają działanie zmierzające do osiągnięcia celu (zaspokojenie potrzeby, rozwiązania zadania), bądź powodują pozbawienie cenionych wartości; sytuacja trudna wyzwala stan wzmożonej aktywizacji i obciąża lub przeciąża system regulacji zachowania" (M. Jarosz, Psychologia lekarska, Warszawa 1978, s. 131).

26 Szerzej do konfliktów rodzinnych zdeterminowanych wadliwą komunikacją odnosi się Sikorski Wiesław. Zob. W. Sikorski, Konflikty $w$ rodzinie uwarunkowane wadliwa komunikacja, [w:] Sytuacje konfliktu w środowisku rodzinnym, szkolnym i rówieśniczym, red. D. Borecka-Biernat, Warszawa 2010, s. 116-135. 
ływanie w rozmowie przykrych sytuacji z przeszłości i obwinianie partnera za nie, choć w przeszłości stanowiły one już przedmiot wyjaśnień.

W płaszczyźnie porozumiewania się członków rodziny należy wyróżnić te elementy komunikacji, które szczególnie warunkują powstanie konfliktu, a są nimi przede wszystkim wyrażanie krytyki, stawianie nieuprawnionych żądań czy odmowa ich spełnienia. Ich funkcja w powstaniu bądź eskalacji konfliktu dotyczy naruszenia norm regulujących stosunki między partnerami interakcji ${ }^{27}$. Wymiana między uczestnikami interakcji negatywnych komunikatów stanowi najbardziej powszechne źródło powstawania konfliktu, który z uwagi na bycie procesem dynamicznym przechodzi przez określone fazy. Pierwszy etap, właściwy jeszcze dla konfliktu ukrytego, odzwierciedla się w uświadomieniu jednostki o zaistniałych różnicach i odmiennościach między pozostałymi uczestnikami interakcji oraz ich subiektywnym zinterpretowaniu ich jako szkodliwe bądź niekorzystne. Fazie tej towarzyszy emocjonalne napięcie oraz poczucie niezadowolenia jednostki. Z kolei podjęte przez nią dalsze działania są uwarunkowane oceną motywacji zaangażowania w konflikt oraz priorytetem spornej kwestii. Druga faza rozwoju konfliktu to jego jawny etap, który przejawia się w aktywności stron we wzajemnym ograniczaniu negatywnych wpływów partnera oraz próbach przywrócenia stanu sytuacji sprzed wystąpienia konfliktu czy doprowadzenia do sytuacji, która przez jednostkę będzie oceniania jako pozytywna i jej sprzyjająca. Etapowi temu towarzyszą kognitywne zniekształcenia percepcji, które w głównej mierze są uwarunkowane wysokim poziomem negatywnych emocji jednostki. Stanowią one rezultat rozczarowania, poczucia frustracji czy złości na postawę drugiej strony, której przypisywane są nierzadko wina

27 Por. Mediacje i negocjacje jako formy rozwiazywania konfliktów, red. S. Tusznio, M. Wojtkowiak, Kielce 2004, s. 16. 
i odpowiedzialność za obecny stan i jakość relacji. W tej fazie najczęściej realizuje się jedna z „iluzji” warunkujących eskalację konfliktu, tj. „iluzja złego człowieka”, która odzwierciedla przekonanie zarówno o złych intencjach drugiej strony, jak i przeświadczenie, że konflikt powstał jako rezultat jej wad i wrogich postaw ${ }^{28}$. Druga faza rozwoju konfliktu decyduje o możliwym dalszym przebiegu sporu w kierunku jego eskalacji lub wspólnym podjęciu negocjacji, mających na celu wypracowanie porozumienia. Dlatego trzeci etap rozwoju konfliktu nawiązuje do jego zakończenia na drodze kompromisu lub do częściowego bądź całkowitego zerwania relacji.

W kontekście prowadzonych rozważań wydaje się szczególnie istotne zwrócenie uwagi na przyjmowane przez jednostki strategie rozwiązywania konfliktów, które warunkują jego rozwiązanie bądź dalszą eskalację. W związku z tym wyróżnia się pięć różnych stylów zarządzania konfliktem ${ }^{29}$, które odzwierciedlają aktywność podejmowanych działań jednostki w dwóch wymiarach, tj. wymiarze współpracy rozumianym jako potrzeba współpracy z innymi w celu osiągnięcia wspólnych rezultatów oraz w wymiarze asertywności interpretowanym jako motywacja jednostki do realizacji indywidualnych celów oraz interesów ${ }^{30}$. Styl dostosowujący rozwiązywania konfliktów preferowany przez jednostkę odzwierciedla strategię wygranej-przegranej, w której jedna ze stron rezygnuje ze swoich potrzeb oraz interesów na rzecz drugiej.

28 Por. D. Dana, Rozwiązywanie konfliktów, tłum. Z. Rummel-Syska, Warszawa 1993, s. 45.

29 Poprzez „zarządzanie konfliktem” autorka rozumie takie intencjonalne i celowe działanie, które wyraża się w próbie podjęcia obiektywnej oceny sytuacji spornej (np. zidentyfikowanie przedmiotu nieporozumienia), rozpoznanie fazy rozwoju konfliktu, wybór oraz zastosowanie właściwej strategii podjęcia konfliktu. Zob. Mediacje. Teoria i praktyka, dz. cyt., s. 56.

30 Por. S. P. Morreale, B. H. Spitzberg, J. K. Barge, Komunikacja między ludźmi, dz. cyt., s. 474-476. 
Styl unikający cechuje zarówno niski poziom współpracy, jak i asertywności stron w pracy nad problemem, co decyduje nierzadko o impasie oraz eskalacji konfliktu. Styl rywalizujący, charakteryzujący się wysokim poziomem asertywności przy niskim poziomie współpracy, decyduje o koncentracji jednostki wyłącznie na indywidualnych aspektach realizacji celów oraz niebraniu pod uwagę szerszego interesu grupy. W kontekście konstruktywnego podejmowania konfliktów oraz przyjmowanych postaw jednostek zarówno wobec sporu, jak i pozostałych uczestników konfliktu, czwarty - współpracujący - styl wydaje się szczególnie ważny i istotny. Styl ten opisuje postawę jednostki charakteryzującą się wysokim poziomem współpracy oraz asertywności, warunkując tym samym spełnienie kryteriów twórczego podejścia do kwestii spornych, stosowanie się do zasad pozytywnej komunikacji oraz koncentracji na osiągnięciu ważnych celów nie tylko z perspektywy funkcjonowania grupy, ale także osobistego rozwoju. Styl piąty, tj. kompromisowy, odzwierciedla strategię zarządzania konfliktem typu „przegrana-przegrana”, tj. konieczności obopólnej rezygnacji stron ze swoich interesów w celu znalezienia wspólnego „środka” rozwiązania sytuacji.

Sytuacje konfliktowe, stanowiąc integralny element przestrzeni życiowej jednostki, decydują tym samym pozytywnie bądź negatywnie o jej rozwoju. W kontekście funkcjonowania rodziny symptomatyczny wydaje się stosunek między stylem zarządzania konfliktami a ich oddziaływaniem na dobrostan pozostałych członków ${ }^{31}$. Wskazuje się jednoznacznie na negatywne skutki małżeńskich kłótni na rozwój dzieci, które będąc świadkami podobnych zdarzeń, doświadczają emocjonalnego dystresu warunkującego nie

31 Por. B. Lachowska, Style rozwiązywania konfliktów $i$ ich efekty $w$ relacji między rodzicami i adolescentami - prezentacja narzędzi pomiaru, [w:] Sytuacje..., dz. cyt., s. 182n. 
tylko poczucie niepokoju, frustracji czy smutku, ale także aktywizującego postawy agresywne ${ }^{32}$. Zachowania szkodliwe decydujące o destruktywnym rozwiązywaniu konfliktów cechuje przede wszystkim przyjmowanie postaw oraz zachowań afektywnych wyrażających gniew, rozczarowanie, irytację, zastraszanie czy szantaż. Rezultaty podobnych postaw oddziałują zarówno na sferę emocjonalną, jak i fizyczną członków rodziny, decydując nierzadko o obniżeniu poczucia bezpieczeństwa, zaufania i chęci nawiązywania bliższych kontaktów.

Konstruktywny charakter konfliktów międzypokoleniowych wyraża się przede wszystkim we wzmocnieniu związków między członkami rodziny poprzez wypracowanie wspólnych strategii podejmowania sporów oraz uzyskanie wiedzy na temat funkcjonujących między nimi rozbieżności; wzroście zaufania, które stanowi rezultat podjęcia wspólnego wysiłku w rozwiązaniu konfliktu, oraz nadziei, że w przyszłości podobne sytuacje trudne również staną się przedmiotem współpracy; podwyższonej samoocenie, która jest uwarunkowana poprawioną usprawnioną psychofizyczną kondycją jednostek na skutek skutecznie i pozytywnie rozwiązanego konfliktu oraz wzbogaceniu twórczości i produktywności jednostek uwarunkowanym poszukiwaniem alternatywnych rozwiązań i przekraczaniem osobistych sfer komfortu w kierunku znalezienia rozwiązania satysfakcjonującego skonfliktowane strony ${ }^{33}$.

Należy zwrócić uwagę, że jednym z warunków konstruktywnie rozwiązanego konfliktu jest pozytywnie przebiegająca komunikacja. Sprzyja ona pogłębieniu wzajemnych relacji, szczerej radości i satysfakcji z racji wspólnego przebywania, wyzwalaniu postaw empatii, życzliwości oraz wyrozumiałości.

32 Por. T. Rostowska, Konflikt międzypokoleniowy $w$ rodzinie. Analiza psychologiczna, Łódź 2001, s. 18-20.

33 Por. tamże, s. 16-18. 


\section{Mediacje w rozwiązywaniu konfliktów rodzinnych}

Transformacja wzorców rodzinnych determinuje powstawanie nowych instytucji oraz instrumentów wspierających rodzinę w realizacji jej funkcji i oferowaniu pomocy w sytuacjach kryzysowych. Definicja mediacji rodzinnej w swym głównym brzemieniu i znaczeniu nie różni się od klasycznej definicji mediacji:

mediacja rodzinna jest procedurą rozwiązywania konfliktu, w której bezstronny i neutralny mediator towarzyszy członkom rodziny $\mathrm{w}$ procesie uzgodnień za ich dobrowolną zgodą oraz przy zachowaniu poufności. Mediator pomaga stronom w zdefiniowaniu kwestii spornych, określeniu potrzeb i interesów stron oraz, o ile taka jest ich wola, wypracowaniu wzajemnie satysfakcjonującego oraz świadomego porozumienia ${ }^{34}$.

Wskazuje się, że niejednoznaczne znaczenie mediacji oraz jej polisemantyczny charakter są podyktowane indywidualnym podejściem każdego mediatora do procesu mediacji, jego etyki pracy, przyjmowanego paradygmatu rozumienia mediacji czy wykorzystywanych metod i technik pracy ze stronami.

W myśl polskiego prawa mediacje w sprawach rodzinnych zaliczane są do prawa cywilnego, dlatego do mediacji rodzinnych stosuje się odpowiednio przepisy właściwe dla mediacji cywilnych, które zawarte są w kodeksie postępowania cywilnego oraz właściwych rozporządzeniach ministra sprawiedliwości. Zgodnie z 10. art. k.p.c: „W sprawach, w których zawarcie ugody jest dopuszczalne, sąd powinien w każdym stanie postępowania dążyć do ich ugodowego załatwienia. W tych sprawach strony mogą także zawrzeć

34 A. Gójska, Mediacja w sprawach rodzinnych. Stan prawny na 11 września 2011, Warszawa 2011, s. 3. 
ugodę przed mediatorem" ${ }^{35}$. W związku z tym precyzyjne skatalogowanie konfliktów, które można zakwalifikować do mediacji, staje się wyzwaniem, ponieważ większość $\mathrm{z}$ nich będzie jej podlegać. Wyjątkiem jest jednak zakres spraw, które dotyczą między innymi ustalania ojcostwa czy praw do spadku, bądź konflikty, w które są zaangażowane strony ze stwierdzoną chorobą psychiczną bądź stosujące przemoc fizyczną lub psychiczną. Generalnie wskazuje się, że to, co nie jest zabronione, można poddać procedurze mediacji ${ }^{36}$.

Chociaż do mediacji rodzinnych stosuje się takie same przepisy, jak do mediacji cywilnych, to niektóre jej aspekty, jak np. sprawy dotyczące warstwy przedmiotowej mediacji, kwalifikacji mediatora czy zasad kierowania do mediacji, są regulowane przez odrębne przepisy ${ }^{37}$. Mediacje rodzinne swój szczególny charakter zawdzięczają przede wszystkim warstwie podmiotowej, tj. udziale w niej osób spokrewnionych lub spowinowaconych ze sobą. Z kolei przedmiotem sporu mogą być zarówno kwestie materialne (np. podział majątku, alimenty), jak i niematerialne (np. sprawowanie opieki nad małoletnim dzieckiem).

Chociaż wydaje się, że mediacje rodzinne nie odbiegają pod względem procedury znacząco od mediacji cywilnych, specyfika konfliktów rodzinnych decyduje o odmiennej naturze mediacji oraz współpracy ze stronami, aniżeli ma to miejsce $\mathrm{w}$ sprawach dotyczących np. prawa pracy lub nieruchomości. Osoby biorące udział w procedurze mediacyjnej decydują o jej przebiegu oraz podejmowanych przez mediatora działaniach ${ }^{38}$.

35 http://prawo.money.pl/kodeks/postepowania-cywilnego/tytul-wstepny-przepisy-ogolne/art-10 (11.11.2014).

36 Por. M. Jaksa, Mediacja cywilna..., dz. cyt., s. 76.

37 Por. art.: 10, 981, 103, 1041, 2021, 2591, $355 \$ 2,436,4452$, 5702 oraz $777 \$ 1$ pkt 21 k.p.c.

38 Por. K. Czayka-Chełmińska, M. Glegoła-Szczap, O specyfice mediacji rodzinnej. Kilka refleksji na marginesie rozwiązań prawnych regu- 
Umowna mediacja w sprawach cywilnych ma miejsce na podstawie sporządzonej przed wystąpieniem sporu klauzuli regulującej relacje między stronami. Z uwagi jednak na nieformalny charakter stosunków rodzinnych podobna klauzula nie funkcjonuje, dlatego strona (lub strony) same zgłaszają inicjatywę podjęcia mediacji bezpośrednio do mediatora bądź ośrodków mediacyjnych, które dysponują listami stałych mediatorów. Innym obliczem mediacji umownych w sprawach rodzinnych jest wcześniejsze zgłaszanie się stron do mediatora w celu wypracowania ustaleń, które później staną się punktem odniesienia w postępowaniu sądowym. W kontekście sytuacji rozwodu czy separacji strony poszukują najczęściej pomocy psychologicznej u mediatora. Wypracowane uprzednio z mediatorem porozumienie nie tylko daje stronom poczucie kontroli, ale także obniża poziom negatywnych emocji i przeżyć związanych z rozstaniem ${ }^{39}$.

Na wysoki status oraz rangę mediacji rodzinnych zwróciła uwagę Rada Europy w jej rekomendacji dla państw członkowskich, koncentrując się między innymi na kwestiach zasad prowadzenia mediacji, organizacji pracy mediatora, promocji instytucji mediacji oraz charakteru konfliktu rodzinnego, który wymaga nierzadko podjęcia alternatywnych działań, mających na celu przywrócenie harmonii i ładu w relacjach między jej członkami ${ }^{40}$. Rekomendacja wskazuje przede wszystkim na korzyści z mediacji w postaci odbudowania atmosfery porozumienia, szczerości, dialogu, zaufania, ograniczenia eskalacji sporu, pomocy w utrzymaniu ciągłości kontaktów oraz obniżeniu ekonomicznych

lujacych $w$ Polsce stosowanie mediacji, [w:] Mediacja, red. L. Mazowiecka, Warszawa 2009, s. 272n.

39 Por. A. Cybulka, Mediacja w sprawach rodzinnych, [w:] Mediacja. Teoria i praktyka, dz. cyt., s. 194.

40 Rekomendacja Nr R (98) 1 Komitetu Ministrów Rady Europy dla państw członkowskich na temat mediacji rodzinnej oraz Memorandum wyjaśniające, ms.gov.pl/pl/dzialalnosc/mediacje/publikacje-akty-prawne-statystyki/download,188,3.html (11.11.2014). 
i społecznych kosztów wynikających ze zjawiska separacji i rozwodu. Centralną kategorią, która stanowi płaszczyznę zawartych w rekomendacji propozycji, jest nie tylko świadomość negatywnego oddziaływania konfliktów rodzinnych na sferę ogólnospołeczną, ale także jednostkową, czyli rodziców, a przede wszystkim również i dziecko. Szczególny charakter tych sporów wynika w głównej mierze $\mathrm{z}$ natury relacji między członkami rodziny nacechowanej wysokim poziomem emocjonalności, przywiązania, nierzadko zależności czy wielowątkowości oraz długości narastania konfliktu. Natężenie przeżywanych emocji między skonfliktowanymi stronami jest tym wyższe, im większa świadomość konsekwencji i realnego oddziaływania sporu na pozostałych członków rodziny oraz ich funkcjonowanie w zaistniałej sytuacji. Warto zaznaczyć, że pozytywne relacje w rodzinie charakteryzuje wysoki poziom synergii, natomiast narastający konflikt negatywnie oddziałuje na poczucie wzajemności, zrozumienia i bezpieczeństwa.

Perspektywa przyjętych założeń decyduje o uwzględnieniu również zebranych w trzy zespoły wyzwań stawianych przed procedurą mediacji, które stanowią rezultat charakteru konfliktów rodzinnych ${ }^{41}$. Pierwszy z nich dotyczy motywacji stron do podjęcia rozmów i skierowanych w przyszłość prowadzonych przez nie negocjacji. Silne emocje związane $\mathrm{z}$ poczuciem bezsilności, frustracji oraz braku zrozumienia nierzadko uniemożliwiają stronie (lub stronom) podjęcie racjonalnych i świadomych decyzji w procesie rozwiązywania konfliktu. Do najważniejszych czynników zniekształcających procesy poznawcze należą między innymi „lustrzane odbicie”, które polega na wzajemnym przeświadczeniu stron o posiadaniu racji w sporze oraz interpretacji zachowań partnera jako niesprawiedliwych i krzywdzących, czy „mechanizm źdźbła i belki”,

41 Por. K. Czayka-Chełmińska, M. Glegoła-Szczap, O specyfice mediacji rodzinnej..., dz. cyt., s. 273-278. 
odzwierciedlający się w dostrzeganiu negatywnej postawy u drugiej strony oraz niedostrzeganiu własnych wad i niewłaściwych zachowań ${ }^{42}$. Rolą mediacji jest odbudowanie pozytywnych relacji w celu porzucenia przez strony strategii skoncentrowanych na wzajemnym zwalczaniu się na rzecz podjęcia konstruktywnej współpracy przeciwko problemowi, pozostawieniu za sobą złości oraz pracy w oparciu o swoje potrzeby i interesy. Istotną funkcją mediacji w zmianie postrzegania stron sytuacji konfliktowej jest zmotywowanie ich do alternatywnego myślenia o swoim konflikcie i przyszłości, co jest możliwe dzięki porzuceniu schematów oraz dotychczas przyjmowanych (a więc subiektywnie interpretowanych jako właściwych i bezpiecznych) mechanizmów działania.

W związku z tym działania mediatora są skierowane głównie na obniżenie napięcia dzięki procesowi „wentylacji emocji”, polegającego na ich nazwaniu i uzewnętrznianiu, wyrażeniu potrzeb czy trosk intencją znalezienia wspólnej płaszczyzny porozumienia. Pozytywna i konstruktywna komunikacja odzwierciedla się szczególności w formułowaniu komunikatów JA, koncentracji na uczuciach drugiej strony oraz empatycznej postawie wobec odmiennego stanowiska drugiej strony. Werbalizacja uczuć i emocji, ustalenie faktycznego przedmiotu sporu i obopólne wysłuchanie się decydują o wzroście poczucia bycia zrozumianym i docenionym. Rolą mediatora jest stworzenie atmosfery i poczucia bezpieczeństwa, możliwości swobodnego dialogu, dostarczanie stronom konstruktywnych oraz twórczych wzorów komunikacji, zmotywowanie stron do nazywania emocji oraz przeżyć czy odróżniania spostrzeżeń od interpretacji ${ }^{43}$.

42 Por. D. W. Johnson, Podaj dtoń, tłum. B. Czarnecka, Warszawa 1992, s. 205 n.

43 Stwierdzenia strony, które są jej interpretacją, zawierają elementy subiektywnej oceny jednostki. Tymczasem obserwacja odwołuje się do 
Drugi zespół wyzwań nawiązuje do zapewnienia bezpieczeństwa i ochrony stronom biorącym udział w mediacji. Dlatego aktywność mediatora jest skoncentrowana wokół jednej z zasad mediacji, jaką jest zapewnienie stronom równości. W przypadku mediacji rodzinnych w głównej mierze może ona dotyczyć równości w wymiarze psychicznym, np. kiedy jedna ze stron wyróżnia się w jasnym formułowaniu swojego stanowiska, dysponuje większymi kompetencjami z zakresu technik negocjacyjnych czy też manipulacyjnych (wykorzystywanymi mniej lub bardziej świadomie). Koncepcję siły w procesie mediacji można interpretować jako poczucie mocy oraz kontroli, których pozytywny bądź negatywny wymiar przesądza ich sposób wykorzystywania ich wobec drugiej osoby ${ }^{44}$. Do pozytywnych przejawów powyższych elementów międzyludzkiej relacji należą np. postawy altruistyczne osób, które oferując swoją wiedzę, pomoc czy dobra materialne, zyskują w otoczeniu poczucie szacunku oraz autorytetu. Ważnymi jednak cechami podobnych relacji są dobrowolność i bezinteresowność w osiąganiu korzyści przez osoby, które wspomnianą siłą i mocą się wyróżniają. Negatywne przejawy nadużywania siły przez strony mogą realizować się zarówno w postaci wywierania wpływu bądź nacisków, jak i w formie gróźb czy zastraszania. Nieformalny charakter siły w związkach rodzinnych wynika z kształtowania się relacji jednostki z otoczeniem. Motywów jej nadużywania należy upatrywać między innymi w potrzebie dominacji, poczuciu bezsilności, strachu przed utratą pozycji lub potrzebą powstrzymania drugiej strony przed osiągnięciem określonego celu, co w kontekście prowadzonych rozważań

np. konkretnych sytuacji, miejsc bądź czasu, co decyduje o traktowaniu ich jako fakty, które odzwierciedlają jednoznaczny punkt odniesienia w prowadzonych rozmowach. Zob. L. Larsson, Porozumienie bez przemocy $w$ mediacjach, tłum. B. Pawłowska-Montwiłł, Warszawa 2009, s. 79n.

44 Por. G. Nordhelle, Sztuka rozwiazywania..., dz. cyt., s. 189-191. 
dotyczących rozwodu lub separacji rodziców oraz emocji i potrzeb związanych $\mathrm{z}$ wychowywaniem dziecka wydaje się szczególnie istotne ${ }^{45}$.

Zadaniem mediatora jest więc podejmowanie prób przywracania równowagi sił stronom, które odzwierciedlają się w jego „zbalansowanym” podejmowaniu działań wobec stron, w których komunikacji i postawach identyfikuje on negatywne wykorzystywanie siły i mocy. Do zadań mediatora należy przede wszystkim doprowadzenie do sytuacji, w której obie strony będą równe wobec siebie w kontekście dysponowania wiedzą na temat tego, co pragną osiągnąć w procesie mediacji oraz umiejętności argumentowania i artykułowania swoich stanowisk, odzwierciedlających potrzeby i interesy ${ }^{46}$. Główną strategią, którą się stosuje w podobnej sytuacji, jest organizacja przez mediatora poufnych spotkań indywidualnych ze stronami, których celem jest w szczególności ograniczenie eskalacji konfliktu, wentylacja emocji, zmotywowanie stron do ujawniania swoich potrzeb czy obaw oraz głębsze zapoznanie się mediatora z łączącym obie strony konfliktem. Z tej przyczyny zadaniem mediatora jest praca ze stronami i maksymalizowanie ich wzajemnych korzyści z zawarcia porozumienia.

Istnieją jednak wyjątki, w których przeprowadzenie procedury mediacji nie jest wskazane. Dotyczy to sytuacji, w których istnieje przypuszczenie bądź pewność mediatora o stosowaniu przez którąś ze stron fizycznej bądź psychicznej przemocy wobec pozostałych osób zaangażowanych w procedurę mediacji ${ }^{47}$. Przywrócenie równowagi sił $\mathrm{w}$ podobnych przypadkach stanowi dla mediatora wyzwanie, które nierzadko skutecznie staje na przeszkodzie

45 Więcej na temat motywów nadużywania siły przez strony w procesie mediacji zob. G. Nordhelle, Sztuka rozwiązywania konfliktów, dz. cyt., s. 191-211.

46 Por. tamże, s. 212n.

47 Por. S. Tusznio, M. Wojtkowiak, Mediacje i negocjacje jako formy..., dz. cyt., s. 131. 
w wypracowaniu porozumienia uwzględniającego potrzeby oraz interesy wszystkich stron. Dlatego zaleca się niekierowanie sprawami, w których istnieje ryzyko występowania patologii, i niepodejmowanie mediacji spraw z uwagi na możliwe poczucie zagrożenia jednej ze stron, stanowiące formę nacisku na zaakceptowanie warunków ugody, które jest proponowane przez drugą stronę sporu.

Trzeci katalog wyzwań w pracy mediatora odnosi się do zapewnienia ochrony i bezpieczeństwa interesów oraz potrzeb dzieci uwikłanych w międzypokoleniowe konflikty. Chodzi tu przede wszystkim o dzieci małoletnie oraz stosowaną $\mathrm{w}$ sytuacji separacji lub rozwodu procedurę mediacji opartą na ustaleniu planu wychowawczego ${ }^{48}$. Jest to konieczne, ponieważ rozpad rodziny odzwierciedla się między innymi w zmianie jej struktury, co szczególnie przez dzieci jest przeżywane jako okres, w którym doświadczają często negatywnych emocji i frustracji związanych z rozejściem się rodziców. Co więcej, w trakcie rozwodu rodzice stają się nierzadko bardziej skoncentrowani na zaistniałym konflikcie aniżeli na aktualnych potrzebach dziecka, które wymaga od nich obojga większej uwagi, empatii, wsparcia, zapewnienia poczucia bezpieczeństwa, stabilności oraz pewnej przewidywalności dnia następnego. Rodzice, skupiając się na wzajemnych oskarżeniach, widzą w tym jedyną metodę osiągnięcia swoich celów. Nierzadko wątek sprawowania opieki nad dzieckiem oraz świadomość chociaż częściowej utraty możliwości sprawowania opieki rodzicielskiej stanowią źródło eskalacji konfliktu. Zachowanie dziecka można interpretować wówczas jako „barometr” panującej między rodzicami atmosfery oraz emocji. Burzliwe kłótnie, w których dochodzi do wzajemnego obwiniania i obrażania się rodziców, a z drugiej

48 Por. Przykładowy Plan opieki rodzicielskiej sformułowany przez Stowarzyszenie Mediatorów Polskich, http://www.smr.org.pl/publikacje/ publikacje-dla-rodzin (06.11.2014). 
strony ograniczanie dziecku informacji na temat nadchodzących zmian, zarówno w relacjach między rodzicami, jak i w funkcjonowaniu dziecka, stanowią czynniki przyjmowania przez nie postaw, które do tej pory były mu obce, np. postaw buntu czy agresji. Kiedy dziecko staje się przedmiotem sporu między rodzicami (np. o prawo do opieki, wysokość alimentów), procedura mediacji stanowi dla rodziców płaszczyznę wsparcia w dojściu do porozumienia.

Funkcja i rola mediacji w ochronie dziecka uwikłanego w konflikt, np. między rodzicami a dziadkami, rozpoczyna się już z chwilą zmniejszenia napięcia emocjonalnego między rodzicami, podjęcia rozmów wyrażających potrzeby oraz nadzieje związane z przyszłością dziecka oraz wzajemnych kontaktów. Jakościowa poprawa komunikacji wyraża się we wzroście poczucia obopólnego zrozumienia i akceptacji. Sprzyja ona także obniżeniu negatywnych emocji uczestników konfliktu, a tym samym pozytywnie wpływa na podejmowane przez nich decyzje, które z odwetowych przekształcają się w konstruktywną motywację podjęcia współpracy. Szczególnym przykładem formy ochrony dziecka w pracy mediatora jest ustalanie wspólnie z rodzicami planu wychowawczego, który odzwierciedla bieżące oraz przyszłe plany i decyzje związane z wychowywaniem dziecka. Uwzględnia on ustalenia dotyczące między innymi, z którym z rodziców dziecko będzie spędzać ważne dla rodziny święta i uroczystości, wakacje, ferie, utrzymywania kontaktów z pozostałymi członkami rodziny, edukacji czy zajęć pozaszkolnych dziecka. Dotychczas wymienione ustalenia pozwalają nie tylko na uniknięcie w przyszłości niejasności i nieporozumień, ale również wypracowanie dostosowanych do potrzeb dziecka wspólnych rozwiązań, mających na celu zapewnieniu mu warunków i atmosfery pozytywnego rozwoju i funkcjonowania.

Końcowe rozważania krótko nawiążą do pozostałych sytuacji, w których także można odwołać się do procedury mediacji, a są nimi przede wszystkimi sprawy rozwodowe 
oraz opiekuńcze, które przewidują między innymi pracę mediatora ze stronami nad Planem opieki rodzicielskiej. Dalej, sprawy z zakresu gospodarowania wspólną własnością, tj. ustaleń dotyczących korzystania ze wspólnego mieszkania, rodzinnych przedsiębiorstw oraz spadków. Szczególny rodzaj spraw stanowią konflikty koncentrujące się wokół sprawowania opieki nad osobami o szczególnych potrzebach. Kwestie związane z planowaniem, realizacją i finansowaniem leczenia czy ustalenia harmonogramu sprawowania dyżurów oraz psychiczne wyzwania, które stawia przed członkami rodziny funkcja pielęgnacji i opieki, decydują nierzadko o powstaniu konfliktów, których źródłem jest poczucie niesprawiedliwości, nadmiernego obciążenia czy braku zrozumienia zaistniałej sytuacji. Ponieważ natura podobnych problemów nie jest regulowana przez prawo, procedura mediacji stanowi alternatywną opcję podjęcia przez rodzinę wspólnych i akceptowalnych decyzji co do zajmowania się osobą, która wymaga szczególnej opieki ze względu na wiek albo chorobę ${ }^{49}$.

\section{Podsumowanie}

Dotychczasowe rozważania pozwalają na sformułowanie paru wniosków o charakterze ogólnym. Wskazuje się na istotną rolę mediacji jako alternatywnego sposobu rozwiązywania sporów w podejmowaniu konfliktów rodzinnych. Statystyki postępowań w sprawach rodzinnych (w sądach powszechnych) odzwierciedlają zarówno coraz większą popularyzację instytucji mediacji, potrzebę jej dalszego promowania, jak i skuteczność podejmowanych działań

49 Por. A. Rękas, Czy tylko sąd rozstrzygnie w sporze? Mediacja i sądownictwo polubowne. Informator o alternatywnych sposobach rozwiazywania sporów, Warszawa 2010, s. 40-45. 
przez mediatorów w dochodzeniu ze stronami do porozumienia $^{50}$.

Szczególny charakter konfliktów między członkami rodziny wynika przede wszystkim $\mathrm{z}$ więzi o charakterze emocjonalnym, sympatii, przywiązania, miłości czy zadaniowym, które stanowią jednocześnie główne źródło satysfakcji oraz zaspokajania potrzeb. Komunikacja w rodzinie odgrywa fundamentalną rolę przede wszystkim z uwagi na jej funkcję wychowywania oraz kontrolowania. Poprzez zachęcanie oraz wspieranie służy ona rozwojowi emocjonalnemu i psychofizycznemu wszystkich członków rodziny. Z kolei funkcja kontrolna zapewnia głównie prawidłowość przebiegu procesów wychowawczych oraz socjalizacyjnych poprzez dawanie wskazówek, porad, wyjaśnień czy wprowadzanie ograniczeń poprzez różne formy dyscypliny ${ }^{51}$.

Występowanie konfliktów w rodzinie postrzega się nie tylko jako naturalne, ale także potrzebne. Dlatego istotne jest, aby konflikty były rozwiązywane w sposób konstruktywny, tj. opierający się na metodzie rozmowy, dyskusji, poszukiwania wspólnych rozwiązań, parafrazy, nazywania swoich emocji oraz potrzeb czy formułowania realnych próśb. Mediacja, stwarzając warunki podjęcia efektywnej komunikacji, motywuje jednostki do pozostania aktywnym oraz konsekwentnym w podejmowaniu konfliktu. Wynika to głównie z poczucia odpowiedzialności za proces mediacji oraz możliwości realnego wpływu na przebieg konfliktu czy poszukiwania alternatyw jego zakończenia.

Istotą i centralnym zamierzeniem alternatywnych sposobów rozwiązywania sporów jest budowa demokratycznego państwa opartego na obywatelach, w których istnieje

50 Por. Mediacje rodzinne w latach 2006 - I półrocze 2014, isws.ms.gov. $\mathrm{pl} / \mathrm{pl} /$ baza-statystyczna/opracowania-wieloletnie (11.11.2014).

51 Por. T. Rostowska, Matżeństwo, rodzina, praca a jakość życia, Kraków 2008, s. 90n. 
potencjał oraz niezbędne możliwości i zdolności do samodzielnego podejmowania konfliktów. Dlatego szczególnie spory o charakterze rodzinnym zaleca się poddawaniu procedurze mediacji oraz umożliwieniu jej autonomicznego wypracowania porozumienia, które uwzględni potrzeby $\mathrm{i}$ interesy wszystkich stron zaangażowanych w konflikt ${ }^{52}$.

W kontekście przywrócenia prawidłowej równowagi i harmonii rodzinie oraz roli mediacji w rozwiązywaniu konfliktów międzypokoleniowych należy zwrócić uwagę na trzy obszary funkcjonowania jej członków ${ }^{53}$. W sferze materialnej zawierają się głównie pomoc socjalna, zaspokojenie podstawowych potrzeb biologicznych oraz ekonomicznych. Sfera duchowa to ponowne odkrywanie sensu i celu życia oraz próba nadania nowego znaczenia takim kategoriom jak wolność, sprawiedliwość, tolerancja czy miłość. Dalej, sfera moralna odnosi się do postaw człowieka wobec dobra oraz zła, dotyczy także ciągłego budowania ładu zarówno w wymiarze zewnętrznym, jak i wewnętrznym jednostki.

Sfery oddziaływania na rodzinę mają związek zarówno z działaniami pomocniczymi z zewnątrz (np. pomoc socjalna państwa), jak i elementami konstytuującymi integrację wewnętrzną rodziny. Zasadę integracji rodziny, którą należy postrzegać jako wzmacnianie sił w niej tkwiących, rozpatruje się w trzech aspektach: normatywnym, funkcjonalnym oraz komunikatywnym ${ }^{54}$. Pierwszy wymiar integracji to określanie rodziny przez pryzmat jej specyficznych struktur, odzwierciedlających się w codziennych relacjach, czynnościach oraz stosunkach. Składają się one na treść wspomnianej relacji, wyznaczając

52 Por. M. Michalak, Mediacja a dziecko, [w:] Mediacja dla każdego, dz. cyt., s. $117 \mathrm{n}$.

53 Por. A. M. de Tchorzewski, Wptyw globalizacji na kondycje polskiej rodziny, [w:] Problemy rodziny na poczatku trzeciego tysiaclecia, red. H. Marzec, M. Pindera, t. I, Piotrków Trybunalski 2007, s. 14.

54 Por. tamże, s. 19. 
tym samym zadania oraz normy, którymi kieruje się w życiu rodzina. Integracja funkcjonalna wynika z ról, jakie pełnią określone osoby w rodzinie (tata, mama, dziadkowie, wujek itd.). Natomiast integracja komunikatywna to ciągłe i aktywne podtrzymywanie więzi opartych na pozytywnej i otwartej komunikacji. Mediacja stwarza warunki i możliwość odbudowania zaburzonych w wyniku konfliktu relacji rodziny głównie na drodze dialogu, który odnosi się do odnowienia fundamentów rodziny opartych na tolerancji, szacunku, wolności oraz możliwości osobistego rozwoju. Dialog, jako droga poznawania rzeczywistości, jest podstawą konstruktywnej komunikacji, kompromisu oraz opisanej integracji, zarówno w rodzinie, jak i w społeczeństwie.

\section{Bibliografia}

Balawajder K., Komunikacja, konflikty, negocjacje w organizacji, Katowice 1998.

Bargiel-Matusiewicz K., Negocjacje i mediacje, Warszawa 2010.

Cebula R., Mediacja $w$ polskim prawie cywilnym. Stan prawny na 1 grudnia 2012, Warszawa 2012.

Czayka-Chełmińska K., Glegoła-Szczap M., O specyfice mediacji rodzinnej. Kilka refleksji na marginesie rozwiazań prawnych regulujacych w Polsce stosowanie mediacji, [w:] Mediacja, red. L. Mazowiecka, Warszawa 2009.

Cybulka A., Mediacja w sprawach rodzinnych, [w:] Mediacja. Teoria i praktyka, red. E. Gmurzyńska, R. Morek, Warszawa 2009.

Dana D., Rozwiązywanie konfliktów, tłum. Z. Rummel-Syska, Warszawa 1993.

Gołębiowski B., Dialog pokoleń: studia nad socjologicznymi i kulturowymi zagadnieniami dialogu i następstwa pokoleń $w$ Polsce XX wieku, Warszawa 1980.

Gójska A., Mediacja w sprawach rodzinnych. Stan prawny na 11 września 2011, Warszawa 2011. 
Harwas-Napierała B., Komunikacja $w$ rodzinie ujmowanej jako system relacji rodzice-dzieci, „Roczniki Socjologii Rodziny” 2006 t. 17, s. 221-233.

Jaksa M., Mediacja cywilna z perspektywy doświadczeń mediatora. Analiza zasad mediacji w przepisach kodeksu postępowania cywilnego, [w:] Alternatywne formy rozwiązywania sporów $w$ teorii i praktyce. Wybrane zagadnienia, red. H. Duszka-Jakimko, S. L. Stadniczeńko, Opole 2008.

Jarosz M., Psychologia lekarska, Warszawa 1978.

Johnson D. W., Podaj dłoń, tłum. B. Czarnecka, Warszawa 1992.

Morreale S. P., Spitzberg B. H., Barge J. K., Komunikacja między ludźmi. Motywacja, wiedza i umiejętności, red. nauk. U. Jakubowska, tłum. P. Izdebski, A. Jaworska, D. Kobylińska, Warszawa 2008.

Lachowska B., Style rozwiąywania konfliktów $i$ ich efekty $w$ relacji między rodzicami $i$ adolescentami - prezentacja narzędzi pomiaru, [w:] Sytuacje konfliktu w środowisku rodzinnym, szkolnym i rówieśniczym, red. D. Borecka-Biernat, Warszawa 2010.

Larsson L., Porozumienie bez przemocy w mediacjach, tłum. B. Pawłowska-Montwiłł, Warszawa 2009.

Latała J., Od idei odwetu po sprawiedliwość naprawcza. Rozważania nad resocjalizacyjnym charakterem instytucji mediacji po wyroku jako formy sprawiedliwości naprawczej, „Probacja” 2010 nr 2, s. $28-51$.

Mediacje. Teoria i praktyka, red. E. Gmurzyńska, R. Morek, Warszawa 2009.

Michalak M., Mediacja a dziecko, [w:] Mediacja dla każdego, red. L. Mazowiecka, Warszawa 2010.

Nęcki Z., Komunikacja międzyludzka, Kraków 1996.

Nordhelle G., Sztuka rozwiązywania konfliktów, Gdańsk 2010.

Płatek M., Cele mediacji w ujęciu porównawczym, [w:] Mediacja dla każdego, red. L. Mazowiecka, Warszawa 2010.

Rostowska T., Konflikt międzypokoleniowy w rodzinie. Analiza psychologiczna, Łódź 2001.

Tchorzewski A. M. de, Wpływ globalizacji na kondycję polskiej rodziny, [w:] Problemy rodziny na początku trzeciego tysiaclecia, red. H. Marzec, M. Pindera, t. I, Piotrków Trybunalski 2007. 
Tusznio S., Wojtkowiak M., Mediacje i negocjacje jako formy rozwiqzywania konfliktów, Kielce 2004.

Rękas A., Czy tylko sąd rozstrzygnie w sporze? Mediacja i sądownictwo polubowne. Informator o alternatywnych sposobach rozwiazywania sporów, Warszawa 2010.

Rostowska T., Matżeństwo, rodzina, praca a jakość życia, Kraków 2008. Wrzesień W., Relacje międzypokoleniowe a rodzina, „Roczniki Socjologii Rodziny” 2000 t. 12, s. 57-70.

Zalewski W., Wymiar sprawiedliwości, sprawiedliwości naprawcza, demokracja, [w:] Mediacja dla każdego, red. L. Mazowiecka, Warszawa 2010.

\section{Źródła internetowe}

http://www.smr.org.pl/publikacje/publikacje-dla-rodzin (06.11.2014).

isws.ms.gov.pl/pl/baza-statystyczna/opracowania-wieloletnie (11.11.2014).

ms.gov.pl/pl/dzialalnosc/mediacje/publikacje-akty-prawne-statystyki/download,188,3.html (11.11.2014).

http://prawo.money.pl/kodeks/postepowania-cywilnego/tytul-wstepny-przepisy-ogolne/art-10 (11.11.2014).

\section{Streszczenie}

Celem podjętych rozważań jest wskazanie szans i możliwych zagrożeń wykorzystania instytucji mediacji jako alternatywnej metody rozwiązywania sporów w konfliktach międzypokoleniowych. Funkcjonowanie rodziny zostaje zawężone do kontekstu komunikacji interpersonalnej. Jednym z warunków konstruktywnie rozwiązanego konfliktu jest pozytywnie przebiegająca komunikacja. Sprzyja ona pogłębieniu wzajemnych relacji, szczerej radości i satysfakcji z racji wspólnego przebywania, wyzwalaniu postaw empatii, życzliwości oraz wyrozumiałości. 
Występowanie konfliktów w rodzinie postrzega się nie tylko jako naturalne, ale także i potrzebne. Dlatego istotne jest, aby były one podejmowane w sposób konstruktywny, tj. opierający się na metodzie rozmowy, dyskusji czy poszukiwania wspólnych rozwiązań. $Z$ kolei rolą mediacji jest odbudowanie pozytywnych relacji w celu porzucenia przez strony strategii skoncentrowanych na wzajemnym zwalczaniu się na rzecz podjęcia konstruktywnej współpracy przeciwko problemowi, pozostawieniu za sobą złości oraz pracy w oparciu o swoje potrzeby i interesy.

Słowa kluczowe: mediacja, konflikt międzypokoleniowy, konflikt, rodzina, alternatywne sposoby rozwiązywania konfliktów, mediacje rodzinne

\section{Summary}

\section{The role and function of mediation in intergenerational family conflicts}

The goal of this discussion is to indicate the advantages, as well as the possible negative effects, of employing mediation as an alternative dispute resolution of intergenerational conflicts. Until now, the functioning of the family has been restricted to the context of interpersonal communication. One of the necessary conditions for constructive conflict resolution is the use of positive communication. It promotes deeper mutual relationships, sincere joy and satisfaction derived from togetherness, and releases the attitudes of empathy, kindness, and tolerance. It is widely accepted that family conflicts are not only natural but also necessary. It is essential therefore that they be dealt with in a constructive manner, i.e., using a method that relies on conversations, discussions, and a search for mutually satisfactory solutions. Mediation can play a role in rebuilding positive relationships, compelling family members to 
abandon infighting and instead to collaborate in combating the problem. Mediation encourages the parties to leave behind their anger and selfishness.

Keywords: mediation, intergenerational conflicts, conflict, family, alternative dispute resolutions, family mediation

Karina Kozłowska, Rola i funkcja mediacji w konfliktach międzypokoleniowych, [w:] Pedagogiczne konteksty spotecznego wsparcia rodziny, red. ks. Grzegorz Godawa, Kraków 2015, s. 206-240.

DOI: http://dx.doi.org/10.15633/9788374384247.07 